\title{
USAGE CHARACTERISTICS OF SPOKEN INDONESIAN LANGUAGE FOR INDIAN SPEAKERS
}

\author{
Wati Istanti ${ }^{1}$, Yanuar Wijayanti ${ }^{2}$ \\ \{istanti_unnes@yahoo.com ${ }^{1}$,yanuarwijayanti415002@gmail.com ${ }^{2}$ \} \\ ${ }^{1,2}$ Universitas Negeri Semarang, Semarang, Indonesia
}

\begin{abstract}
Indian speakers have the characteristics of using the Indonesian language, which becomes their characteristics, especially in a variety of spoken words. Linguistics diversity in the verbal form or speaking skills is essential to review because the usage of language is very influential toward the delivered information. The goal of this research is to know the characteristics owned by Indian speakers when using the Indonesian language. The result of this research shows that Indian speakers have features in using the Indonesian language in the aspect of sentence structures, vocabularies, and dialect.
\end{abstract}

Keywords: characteristics, spoken language, Indian speakers

\section{INTRODUCTION}

Along with the determined goals by the Indonesian nation in this global era, the role of Indonesia in the inter-nation relationship has placed Indonesia as one of the considered countries in the world. Forty-five states with at least 130 agencies; highed education, cultural centers, the embassy of the Republic of Indonesia, and language courses; have studied the Indonesian language. The newest data from the educational and cultural attache of Indonesia at Embassy of the Republic of Indonesia in India stated that there were 60 Indonesian as a Foreign Language (here and after called as IFL) students from three levels, those are there were 32 students in A1 class, 9 students in A2, and 11 students in B1.

The development of the global world and current free trade give impact to the number of foreigners who work and study in Indonesia, especially Indian speakers. One of the needs of those foreign workers is learning the Indonesian language for daily requirement basis and business to be able to survive in Indonesia. Indian speakers are very enthusiastic about learning IFL as a mean to reach the goals, such as politics, trades, art and culture, and tourism. It is caused by the position of Indonesia in the world become more and more important, either by contributing to solving the political conflicts in any region or because of very strategic geographical locations.

The interest of Indians to learn IFL become more escalating after the ASEAN Economic Community (AEC) implemented. AEC is the commitment of ASEAN to build and reach commonwealth with a motto One Vision, One Identity, and One Commitment. That condition strengthens the establishment of a single market. In contrast, ASEAN member states are easier 
to exchange the flow of commodities and services, including professional human resources such as doctors, nurses, teachers, and lawyers.

The number of foreign investment which invested in Indonesia is getting higher each year. The increase of that investment number is followed by the growth of expatriates in Indonesia, especially in Central Java Province. There are about 1.430 Indian speakers in Central Java Province with more or less of them have studied IFL

The characteristics of the application of language are the existence of unique features represents the people's behavior in using a particular language. Each country surely has aspects of its language, including India. The most prominent element is the pronunciation of [П] sound, which becomes [n-g] sound if it is pronounced in the wrong syllable and as an example is the word /tangan/ pronounced as /tan-gan/, not /ta-ngan/. That condition in line with Susanto's statement[1]. That there are particular features in every language believed will cause learners to face difficulties in learning other languages. The unique features in the first language, which are mastered by the language learners, will affect and trigger straits for language learners when learning foreign languages.

Teaching the Indonesian language as a foreign language for non-native speakers is classified into three levels; those are novice, intermediate, and advanced which covers four language skills, namely listening, speaking, reading and writing. Speaking ability is vital to be mastered for communication because the occurred mistake in speaking could affect the information or the conveyed meaning to the interlocutor through speech[2]. The structure of language reflects user functions and communicative functions [3]. One of the considered factors in speaking is speech accuracy or pronunciation because it could hinder the effectiveness of communication. teaching methods, the influence of classmates and textbooks are important factors that generally affect students' choices about vocabulary learning strategies[4]

\section{METHOD}

This research uses descriptive methodology with the content analysis technique. A descriptive study is a research method which tries to describe and interpret the object as it is. The content analysis technique is used to classify the attributes used in communication, use criteria in classification, and implement specific technical analysis in produce prediction[5]. Content analysis is a technique to identify the characteristics of the messages or information which does not source from the written content of the communication. This technique is used to explain or describe the facts on the research object and the other aspects as the primary concern in the research[6]. This research describes the characteristics of Indian speakers.

\section{RESULT AND DISCUSSION}

Based on the previous research, there are three characteristics of language usage by Indian speakers, namely sentence structure, vocabularies and dialect. The used sentence structure by Indian speakers is excellent and already correct with the provision of Indonesian grammar. The characteristics of the sentence structure of the Indian speaker more stresses on the use of preposition and double conjunctions in the sentences, and the use of preposition "dan" at the beginning of the sentence. The second characteristic, vocabulary characteristic, is loan words. The third characteristic is the dialect characteristic. 
a. Sentence Structure

The use of preposition and double conjunction, including conjunction "dan" at the beginning of the sentence is the found characteristics in this research. The meaning of double preposition in this research is that there are two same prepositions in one sentence. The same case occurs in double conjunction. The followings are data on the use of preposition and double conjunction by Indian speakers.

${ }^{(1)}$ Saya sedang belajar di program ILCA di UNNES.

${ }^{(2)}$ Saya bangga bisa belajar bahasa Indonesia di kedutaan Indonesia di New Delhi.

${ }^{(3)}$ Di kelas ini saya juga belajar tentang desain batik dan melakukannya secara practice di kelas dan kesenian Indonesia dengan guru BIPA.

${ }^{(4)}$ Saya pergi ke Indonesia dari program darmasiswa.

Those sentences are sentences which have double preposition on it, and those are preposition "di", "ke" and "dari". Then, it uses conjunction "dan" twice in the sentence (3). The use of preposition and double conjunction cause spoken language produced by Indian speakers ineffective. Preposition " $d i$ " (1) must be omitted to make the produced sentence more productive and comfortable to hear. Saya sedang belajar di program ILCA UNNES. The sentence (3) will be more effective if it breaks into two sentences. Di kelas ini saya juga belajar tentang desain batik dan melakukannya secara practice di kelas. Saya juga belajar kesenian Indonesia dengan guru BIPA.

Indian speakers also have characteristics to use conjunction "dan" at the beginning of the sentence. There are two requirements for a conjunction which possibly placed at the beginning of the sentence; those are containing minimum of two clauses and two connectors to connect it (inter sentence connector). Conjunction " $d a n$ " is not included those requirements, so a sentence could not be started with conjunction "dan".

${ }^{(5)}$ Dan budaya Hindu.

${ }^{(6)}$ Dan saya juga belajar memasak makanan Indonesia.

The reason for using conjunction "dan" at the beginning of the sentence is usually caused by the speakers want to explain many things in one sentence. That sentence is divided into two because it is assumed that sentence is too long, so it causes the conjunction "dan" is placed at the beginning of the sentence.

\section{b. Vocabularies}

The loan words which are often found in the Indian speakers' speech are loan words from English language. It is caused by the national language in India is English, so it is possible that the Indian speakers will pronounce the vocabularies in English phonetics style if its orthography and pronunciation are almost similar to the Indonesian language.

${ }^{(7)}$ Saya tinggal di /campus/ New Delhi.

${ }^{(8)}$ Ini menara /icon/ dari kota Kudus. 
${ }^{(9)}$ Di kelas ini saya juga belajar tentang /design/ batik dan melakukannya secara /practice/ di kelas dan kesenian Indonesia dengan guru BIPA.

Indian speakers often pronounce English vocabularies to pronounce Indonesian vocabularies, such as /campus/ should be pronounced as /kampus/, /icon/ should be pronounced as /ikon/, /design/ should be pronounced as /desain/, and /practice/ should be pronounced as /praktik/. The same meaning also become the firm reason why Indian speakers prefer to use those vocabularies because those vocabularies are not only the most recalled but also the most used.

\section{c. Dialect}

The third characteristic owned by Indian speakers is their pronunciation is influenced by their first language dialect, which is the nasal sound [ng] in the middle of the pronounced word $[\mathrm{n}-\mathrm{g}]$, which means sound $[\mathrm{n}]$ separated from sound $[\mathrm{g}]$.

\section{${ }^{(9)}$ Di kelas ini saya juga belajar tentang design batik dan melakukannya secara practice di kelas dan kesenian Indonesia dengan guru BIPA. \\ ${ }^{(10)}$ Cilacap dekat di pulau Nusa Kambangan.}

Based on the research, words which have nasal sound [ng] in the middle syllable, always pronounced as [ngg] by Indian speakers. The word /dengan/ is pronounced as/den-gan/ and the word /Kambangan/ is pronounced as /Kamban-gan/. Such nasal sounds are difficult for them to pronounce it, so there must be separation on the wrong syllables.

\section{CONCLUSION}

Based on the results of the research, it could be inferred that there are some aspects which become the characteristics in sing Indonesian language by Indian speakers: (1) sentence structure: the use of preposition and double conjunction, including conjunction "dan" in the beginning of the sentence; (2) vocabularies: the usage of loan words from English language; and (3) dialect: pronunciation of the $[\mathrm{ng}]$ in middle of the syllable.

\section{REFERENCE}

[1] G. Susanto, "Pengembangan Bahan Ajar Bipa Berdasarkan Kesalahan Bahasa Indonesia," Bhs. Dan Seni, vol. 35, no. 2, pp. 231-239, 2007.

[2] R. Raden Yusuf Sidiq Budiawan, "Kesalahan Bahasa Dalam Praktik Berbicara Pemelajaran Bahasa Indonesia Bagi Penutur Asing (Bipa) Di Universitas Pgri Semarang Tahun 2018," KREDO J. Ilm. Bhs. dan Sastra, vol. Vol 2 No 1, no. 1, 2018.

[3] I. Suyitno, "Learning indonesian for foreigner based on indonesian culture," no. March, 2017.

[4] S. Kameli, G. Bin Mostapha, and R. Bin Baki, "The Influence of Formal Language Learning Environment on Vocabulary Learning Strategies," J. Lang. Teach. Res., vol. 3, no. 1, pp. 23-29, 2012.

[5] Sukardi, Educational Research methodology, Competencies and Practices. Jakarta: Bumi Aksara, 2008.

[6] J. R. dan N. E. W. Frankel, How to Design and Evaluate Research in Education. New 
York: McGraw Hill Inc, 1993. 